\title{
In Vitro Plant Regeneration of Andrographis Paniculata Nees Using Mature Zygotic Embryonic Explants
}

\author{
Vikram Paritala, Arifullah Mohammed ${ }^{1 *}$ and Fatimah Kayat \\ Department of Agro Based Industry, Universiti Malaysia Kelantan Jeli Campus, Malaysia
}

Submission: February 05, 2017; Published: April 12, 2017

"Corresponding author: Arifullah Mohammed, Department of Agro Based Industry, Universiti Malaysia Kelantan Jeli Campus, 17600, Jeli, Kelantan, Malaysia, Email: aurifullah@umk.edu.my

\begin{abstract}
A rapid method for the large-scale propagation of Andrographis paniculata through in vitro culture of embryonic explants has been developed. Adventitious shoot regeneration from embryonic explants was possible in case of cotyledons and root decapitated embryonic axis among all the tested embryonic explants. High frequency of adventitious shoot formation (?) was observed within 30 days from embryonic explants and shoot induction followed either direct regeneration on MS medium supplemented with BAP or indirect adventitious shoot regeneration in TDZ. BAP was more effective than other cytokinins used for direct adventitious shoot induction from both the embryonic explants of A. panicualata with BAP $1.5 \mathrm{mg} / \mathrm{L}$ producing $73 \%$ shooting and 12.3 shoots per explants while study in cotyledons showed best response in BAP $3.0 \mathrm{mg} / \mathrm{L}$ with $52 \%$ shooting and 9.3 shoots per explants. While TDZ $1.0 \mathrm{mg}$ was effective in indirect shoot regeneration among the different concentrations tested with $26 \%$ shoot regeneration from embryonic axis with 3.3 shoots and $76 \%$ from cotyledons with 6 shoots per explants. Shoots elongated in MS media with GA $0.5 \mathrm{mg} / \mathrm{L}$ are effectively rooted in half strength MS media with IBA $0.5 \mathrm{mg} / \mathrm{L}$ and a high percentage of (82.5\%) plants were successfully hardened in soil, sand and vermiculite $(1: 1: 1)$.
\end{abstract}

Keywords: Cotyledons; Decapitated embryonic axes; Direct shoot organogenesis; BAP; TDZS

\section{Introduction}

The use of herbal medicine has increased significantly in the last decade resulting in a huge impact on the medicinal plants and especially those collected from the wild [1]. Medicinal plants with elite characteristics and large quantity of planting material is an important prerequisite in medicinal plant culture for producing large quantities of phytochemicals. Tissue culture is the most often used technique for producing large quantity of elite planting material for past 30 years. Organogenesis is the most common way of in vitro regeneration and is the rate determining step for successful propagation in plants. Adventitious shoot organogenesis is a reliable technique for clonal propagation as it produces large number of plantlets in a short time and less resources. The propagation rates via organogenesis can be much higher than auxiliary shoot proliferation [2]. The occurrence of uncontrolled and random spontaneous variation during adventitious organogenis is a major problem [3]. Direct adventitious shooting without an intervening callus phase minimises these variations [4] and the plants produced were genetically stable [5] whereas regeneration via an intermediate callus phase increases the possibility of somaclonal variations [6].

Andrographis paniculata is a potential medicinal plant with medicinal activities ranging from common cold to fatal cancer. It is vividly used in traditional systems of almost all East Asian, South and South East Asian countries. The main active ingredients are believed to be lactone terpenoids especially andrographolide, dehydroandrographolide, neoandrographolide and deoxyandrographolide [7]. Andrographolide is proved to be effective in treatment of various diseases conditions like inflammation, cold, HIV, cancer and in developmental stage of being incorporated as anti cancer drug [8]. The conventional methods of propagation in A. paniculata are difficult and slow with problems in seed germination [9].

Although there is existing protocols of micropropagation in A. paniculata using leaf and node explants a new, simple and efficient method was developed for multiple shoot regeneration 
using embryo explants. The choice of an effective explant is a basic requirement for plant regeneration protocol $[5,10]$. Embryo culture is an important milestone for mass micro propagation in many plants along with relactariants because of their juvenile nature [11] and can be manipulated by growth regulators resulting in adventitious bud formation [12]. Embryonic explants have been used for micropropagation and genetic transformation [13]. Direct shoot regeneration has been reported in many plants from zygotic embryo explant in Boscia Senegalensis [14], Cajanus cajan [15], from decapitated embryonic axes in Cicer arietinum [16], Clitoria ternatea [17] and cotyledons in Benincasa hispida [18] and Ricinus communis [19].

\section{Materials and Methods}

\section{Sterilization of explants}

Partially matured pods were rinsed twice with sterile distilled water then immersed in $75 \%$ ethanol for $1 \mathrm{~min}$, rinsed with sterile distilled water once and immersed for $10 \mathrm{~min}$ in a solution of $5 \%$ sodium hypochlorite and $1 \mathrm{ml}$ Tween 20 and rinsed thrice in sterile distilled water. Embryos were dissected out and cotyledons and embryonic axes with decapitated root apices were used as explants.

\section{Types of embryonic explants used}

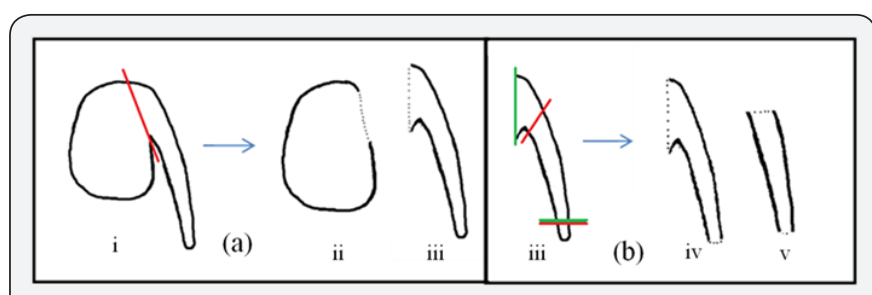

Figure 1: Preparation of different $A$. paniculata embryonic explants, a) (i) embryo dissected into (ii) cotyledon and (iii) embryonic axes, b) embryonic axes dissected into (iv) embryonic axes with decapitated root tip and (v)embryonic axes with decapitated shoot and root tip.

In this study, the embryos were cut forming four types of explants along with embryo as fifth explant were used to know shoot forming capability (Figure 1). The first one cotyledons, second one embryonic axis, the third one embryonic axes prepared by cutting a small part of rooting end from the bottom and the fourth one by cutting shoot meri stem from the top and a small part of rooting end from the bottom of the embryonic axes. The 5 types of explants were cultured in MS media (1962) supplemented with BAP 1.5mg/l to determine the explants with multiple shooting efficiency.

Multiple shoot induction: Cotyledons and root decapitated embryonic axes were cultured on Murashige and Skoog (1962) media formulations with different combinations of cytokinins (BAP, KIN, 2 IP) at concentrations (1.0, 1.5, 2.0 and 3.0mg/L) and auxins (NAA and IBA) at concentrations $(0.5,0.75$ and $1.0 \mathrm{mg} / \mathrm{L})$ and TDZ $(0.1,0.25,0.5,0.75,1.0 \mathrm{mg} / \mathrm{L})$ were used to determine the optimum concentration and types of growth regulators that favoured rapid and efficient in vitro regeneration. All the media contained $3 \%$ sucrose and were gelled with $0.8 \%$ agar. Plant growth regulators were added to the media under sterile conditions and the $\mathrm{pH}$ was adjusted to 5.8 before autoclaving at $1.06 \mathrm{~kg} \mathrm{~cm}-2\left(121{ }^{\circ} \mathrm{C}\right)$ for $20 \mathrm{~min}$. The explants cultured in media were transferred to dark condition for 10 days followed by light under $16 \mathrm{~h}$ day-light, at $55 \mu \mathrm{mol} \mathrm{m} \mathrm{m}^{-2} \mathrm{~s}^{-1}$ provided by daylight fluorescent Philips tubes with growth room temperatures at $25 \pm 0.5^{\circ} \mathrm{C}$.

Rooting and Acclimatization: Proliferated multiple shoots with an average height of $1 \mathrm{~cm}$ were carefully excised from the cut edges of explants were segregated into small clusters containing two to three shoots. These shoot clusters were transferred to shoot elongation medium containing Gibberellic acid (GA3) 0.5 and elongated shoots ( $>2 \mathrm{~cm}$ in height) were transferred to $1 / 2 \mathrm{MS}$ medium containing IBA $0.5 \mathrm{mg} / \mathrm{L}$. The cultures were maintained as described for shoot elongation. After 4 weeks the rooted plants were transplanted to paper cups containing soil, sand and vermiculite (1:1:1) and were placed in green house.

All the experiments were repeated thrice with 15 explants for each treatment and data were analyzed by Duncan's Multiple Range Test (DMRT) and significance was determined at $\mathrm{P} \leq 0.05$ level.

\section{Results}

Table 1: Effect of different A. paniculata embryonic explants on shoot regeneration in MS media containing BAP $1.5 \mathrm{mg} / \mathrm{L}$.

\begin{tabular}{|c|c|c|}
\hline Type of Explant & $\begin{array}{c}\text { Percentage } \\
\text { Growth } \\
\text { Response }\end{array}$ & $\begin{array}{c}\text { Percentage } \\
\text { Shooting } \\
\text { Response }\end{array}$ \\
\hline Embryo & $91.1 \pm 2.2 \mathrm{a}$ & NR \\
\hline Embryo axes & $88.9 \pm 5.9 \mathrm{a}$ & $4.4 \pm 2.2 \mathrm{c}$ \\
\hline Cotyledon & $84.4 \pm 2.2 \mathrm{a}$ & $24.4 \pm 2.2 \mathrm{~b}$ \\
\hline $\begin{array}{c}\text { Root decapitated } \\
\text { embryonic axes }\end{array}$ & $68.9 \pm 5.9 \mathrm{~b}$ & $62.2 \pm 5.9 \mathrm{a}$ \\
\hline $\begin{array}{c}\text { Shoot and root } \\
\text { decapitated } \\
\text { embryonic axes }\end{array}$ & $2.2 \pm 2.2 \mathrm{c}$ & $\mathrm{NR}$ \\
\hline
\end{tabular}

Observations after 45 days, means \pm standard error followed by the same alphabet in the same column are not statistically different $(P<0.05)$, NR-no response.

In vitro direct adventitious shoot regeneration protocol from embryonic explants was developed for rapid multiplication of $A$. panicualata. Shoot induction was studied in embryo, cotyledons, embryonic axes, embryonic axes with decapitated root and embryonic axes with decapitated shoot and root. Of all the five types of explants chosen, cotyledons and embryonic axes with decapitated root end was able to produce shoots with shooting responses of $24 \%$ and $62 \%$ (Table 1) while full embryos and embryonic axis were germinated forming plantlets, embryonic axis with decapitated shoot and root was completely unable to show growth response (Figure 2). 


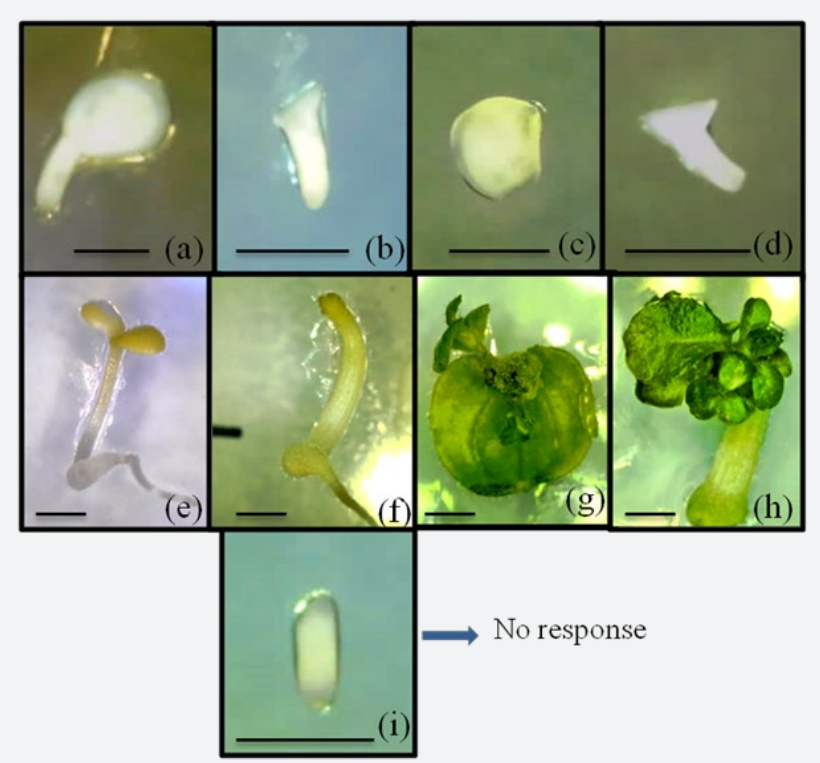

Figure 2: Growth response of different $A$. paniculata embryonic explants on MS media containing BAP $1.5 \mathrm{mg} / \mathrm{L}, \mathrm{a})$ embryo, b) embryo axes, c) cotyledon, d) root decapitated embryo axes, e) germinated embryo, f) germinated embryo axes, g) shooting from cotyledons, h) shooting from root decapitated embryo axes and i) shoot, root decapitated embryo axes. Bar= $2 \mathrm{~mm}$.

Plantlets were efficiently regenerated by both directand indirect unable to produce shoots (Table 2 \& 3). Decapitated embryonic axes adventitious shooting from seed-derived cotyledon and decapitated produced more shooting percentage and shoot number compared embryonic axes explants in MS media containing BAP, BAP+IBA, to cotyledons by direct regeneration where as cotyledons produced TDZ 1.0mg/L, 2 IP 3mg/L while BAP+NAA, KIN, KIN+IBA, KIN+NAA, more shooting percentage (Table 2) and shoot number compared to 2 IP 1, 1.5, 2mg/L, 2 IP +IBA, 2 IP +NAA, TDZ 0.1, 0.25, 0.5, 0.75 were decapitated embryo axes in indirect regeneration (Table 3).

Table 2: Effect of different PGRs on shooting response from root decapitated embryonic axes of A. paniculata

\begin{tabular}{|c|c|c|c|c|}
\hline Pgrs Used (Mg/L) & Percentage Growth Response & Percentage Shooting Response & Average & No. of Shoots/Explants \\
\hline BAP 1.0 & $35.5 \pm 2.2 \mathrm{ij}$ & $53.3 \pm 6.7 \mathrm{~b}$ & & $3.7 \pm 0.9 \mathrm{~cd}$ \\
\hline BAP 1.5 & $68.9 \pm 9.7 \mathrm{bcde}$ & $73.3 \pm 3.3 \mathrm{a}$ & & $12.3 \pm 1.4 \mathrm{a}$ \\
\hline BAP 2.0 & $46.7 \pm 6.7 \mathrm{ghi}$ & $42.9 \pm 8.2 b c$ & & $6.7 \pm 1.2 \mathrm{~b}$ \\
\hline BAP 3.0 & $44.3 \pm 4.4 \mathrm{hi}$ & $19.0 \pm 4.8 \mathrm{de}$ & & $6.0 \pm 1.0 \mathrm{bc}$ \\
\hline BAP $1.0+$ IBA 0.5 & $57.8 \pm 8.0 \mathrm{efgh}$ & $22.2 \pm 6.4 \mathrm{de}$ & & $2.7 \pm 0.3 \mathrm{~cd}$ \\
\hline BAP $1.5+$ IBA 0.75 & $64.4 \pm 8.0$ defg & $33.3 \pm 3.3 \mathrm{~cd}$ & & $5.0 \pm 0.6 \mathrm{bcd}$ \\
\hline BAP 2.0+IBA 1.0 & $46.7 \pm 10.2 \mathrm{ghi}$ & $19.0 \pm 4.8 \mathrm{de}$ & & $3.3 \pm 0.9 \mathrm{~cd}$ \\
\hline BAP $1.0+$ NAA 0.5 & $91.1 \pm 4.4 \mathrm{a}$ & NR & & NR \\
\hline BAP 1.5+NAA 0.75 & $82.2 \pm 5.9 \mathrm{abcd}$ & NR & & NR \\
\hline BAP $2.0+$ NAA 1.0 & $57.8 \pm 5.9 \mathrm{efgh}$ & NR & & NR \\
\hline KIN 1.0 & $35.6 \pm 8.0 \mathrm{ij}$ & NR & & NR \\
\hline KIN 1.5 & $48.9 \pm 4.4$ fghi & NR & & NR \\
\hline KIN 2.0 & $35.6 \pm 5.9 \mathrm{ij}$ & NR & & NR \\
\hline KIN 3.0 & $31.1 \pm 5.9 \mathrm{ij}$ & NR & & NR \\
\hline KIN 1.0+IBA 0.5 & $22.2 \pm 5.9 \mathrm{j}$ & NR & & NR \\
\hline KIN 1.5+IBA 0.75 & $42.2 \pm 5.9 \mathrm{hi}$ & NR & & NR \\
\hline KIN 2.0+IBA 1.0 & $77.8 \pm 5.9$ abcde & NR & & NR \\
\hline KIN 1.0+NAA 0.5 & $66.7 \pm 3.8$ cdef & NR & & NR \\
\hline KIN 1.5+NAA 0.75 & $71.1 \pm 5.9$ abcde & NR & & NR \\
\hline KIN 2.0+NAA 1.0 & $84.4 \pm 5.9$ abcd & NR & & NR \\
\hline 2-iP 1.0 & $71.1 \pm 5.9$ abcde & NR & & NR \\
\hline
\end{tabular}




\section{Agricultural Research \& Technology: Open Access Journal}

\begin{tabular}{|c|c|c|c|}
\hline 2-iP 1.5 & $82.2 \pm 2.2 \mathrm{abcd}$ & NR & NR \\
\hline 2-iP 2.0 & $86.7 \pm 6.7 \mathrm{abc}$ & NR & NR \\
\hline 2-iP 3.0 & $75.6 \pm 8.0$ abcde & $15.1 \pm 3.0 \mathrm{e}$ & $4.3 \pm 0.3 \mathrm{bcd}$ \\
\hline 2-iP $1.0+$ IBA 0.5 & $35.6 \pm 5.9 \mathrm{ij}$ & NR & NR \\
\hline 2-iP 1.5+IBA 0.75 & $44.4 \pm 8.0 \mathrm{hi}$ & NR & NR \\
\hline 2-iP 2.0+IBA 1.0 & $28.9 \pm 2.2 \mathrm{ij}$ & NR & NR \\
\hline 2-iP $1.0+$ NAA 0.5 & $77.8 \pm 4.4$ abcde & NR & NR \\
\hline 2-iP 1.5+NAA 0.75 & $82.2 \pm 5.9$ abcd & NR & NR \\
\hline 2-iP 2.0+NAA 1.0 & $75.6 \pm 4.4$ abcde & NR & NR \\
\hline TDZ 0.1 & $83.3 \pm 3.3 \mathrm{abcd}$ & NR & NR \\
\hline TDZ 0.25 & $88.9 \pm 5.9 \mathrm{ab}$ & NR & NR \\
\hline TDZ 0.5 & $84.4 \pm 5.9 \mathrm{abcd}$ & NR & NR \\
\hline TDZ 0.75 & $77.8 \pm 5.9$ abcde & NR & NR \\
\hline TDZ 1.0 & $68.9 \pm 5.9$ bcde & $26.7 \pm 3.3 \mathrm{de}$ & $3.3 \pm 0.3 \mathrm{~cd}$ \\
\hline
\end{tabular}

Observations after 45 days, means \pm standard error followed by the same alphabet in the same column are not statistically different $(P<0.05)$, NR-no response.

Table 3: Effect of different PGRs on shooting response and on multiple shoot induction from cotyledons of A. paniculata.

\begin{tabular}{|c|c|c|c|}
\hline Pgrs Used (Mg/L) & Percentage Growth Response & Percentage Shooting Response & Average No. Of Shoots/Explant \\
\hline BAP 1.0 & $86.7 \pm 3.8$ abcdef & $12.8 \pm 2.6 \mathrm{de}$ & $3.00 \pm 0.00 \mathrm{~d}$ \\
\hline BAP 1.5 & $91.1 \pm 2.2 \mathrm{abcd}$ & $21.4 \pm 4.1 \mathrm{~cd}$ & $5.00 \pm 1.00 \mathrm{bc}$ \\
\hline BAP 2.0 & $93.3 \pm 3.8 \mathrm{abc}$ & $26.2 \pm 4.8 \mathrm{c}$ & $6.67 \pm 0.88 \mathrm{~b}$ \\
\hline BAP 3.0 & $95.6 \pm 2.2 \mathrm{ab}$ & $52.4 \pm 2.4 \mathrm{~b}$ & $9.33 \pm 0.33 \mathrm{a}$ \\
\hline BAP $1.0+$ IBA 0.5 & $95.6 \pm 2.2 \mathrm{ab}$ & $11.9 \pm 2.4 \mathrm{de}$ & $2.33 \pm 0.33 \mathrm{~d}$ \\
\hline BAP $1.5+$ IBA 0.75 & $91.1 \pm 2.2 \mathrm{abcd}$ & $23.8 \pm 2.4 \mathrm{c}$ & $4.00 \pm 0.57 \mathrm{~cd}$ \\
\hline BAP $2.0+$ IBA 1.0 & $77.8 \pm 5.9$ defgh & $5.6 \pm 2.8 \mathrm{e}$ & $2.33 \pm 0.33 \mathrm{~d}$ \\
\hline BAP $1.0+$ NAA 0.5 & $91.1 \pm 2.2$ abcd & NR & NR \\
\hline BAP 1.5+NAA 0.75 & $84.4 \pm 2.2$ abcdef & NR & NR \\
\hline BAP $2.0+\mathrm{NAA} 1.0$ & $75.5 \pm 2.2$ efgh & NR & NR \\
\hline KIN 1.0 & $31.1 \pm 2.2 \mathrm{k}$ & NR & NR \\
\hline KIN 1.5 & $40.0 \pm 3.8 \mathrm{ijk}$ & NR & NR \\
\hline KIN 2.0 & $44.4 \pm 2.2 \mathrm{ij}$ & NR & NR \\
\hline KIN 3.0 & $33.3 \pm 3.9 \mathrm{jk}$ & NR & NR \\
\hline KIN 1.0+IBA 0.5 & $71.1 \pm 5.9 \mathrm{fgh}$ & NR & NR \\
\hline KIN 1.5+IBA 0.75 & $64.4 \pm 2.2$ abcdef & NR & NR \\
\hline KIN 2.0+IBA 1.0 & $48.9 \pm 2.2$ cdefg & NR & NR \\
\hline KIN 1.0+NAA 0.5 & $71.1 \pm 4.4$ fgh & NR & NR \\
\hline KIN 1.5+NAA 0.75 & $64.4 \pm 2.2 \mathrm{~h}$ & NR & NR \\
\hline KIN 2.0+NAA 1.0 & $48.9 \pm 2.2 \mathrm{i}$ & NR & NR \\
\hline 2-iP 1.0 & $91.1 \pm 2.2 \mathrm{abcd}$ & NR & NR \\
\hline 2-iP 1.5 & $91.1 \pm 5.9$ abcd & NR & NR \\
\hline 2-iP 2.0 & $88.9 \pm 8.0$ abcde & NR & NR \\
\hline 2-iP 3.0 & $84.4 \pm 5.9$ abcdef & NR & NR \\
\hline 2-iP $1.0+$ IBA 0.5 & $68.9 \pm 5.9 \mathrm{hi}$ & NR & NR \\
\hline 2-iP1.5+IBA 0.75 & $82.2 \pm 5.8$ bcdefg & NR & NR \\
\hline 2-iP 2.0+IBA 1.0 & $86.7 \pm 3.8$ abcde & NR & NR \\
\hline 2-iP 1.0+NAA 0.5 & $82.2 \pm 2.2 \mathrm{bcdefg}$ & NR & NR \\
\hline 2-iP $1.5+\mathrm{NAA} 0.75$ & $95.6 \pm 2.2 \mathrm{ab}$ & NR & NR \\
\hline
\end{tabular}


Agricultural Research \& Technology: Open Access Journal

\begin{tabular}{|c|c|c|c|}
\hline 2-iP $2.0+$ NAA 1.0 & $82.2 \pm 2.2$ bcdefg & NR & NR \\
\hline TDZ 0.1 & $84.4 \pm 5.9$ abcdef & NR & NR \\
\hline TDZ 0.25 & $91.1 \pm 2.2$ abcd & NR & NR \\
\hline TDZ 0.5 & $97.8 \pm 2.2 \mathrm{a}$ & NR & NR \\
\hline TDZ 0.75 & $88.9 \pm 5.9$ abcde & $76.9 \pm 4.4 \mathrm{a}$ & $6.0 \pm 0.6 \mathrm{~b}$ \\
\hline
\end{tabular}

Observations after 45 days, means \pm standard error followed by the same alphabet in the same column are not statistically different $(P<0.05)$, NR-no response.
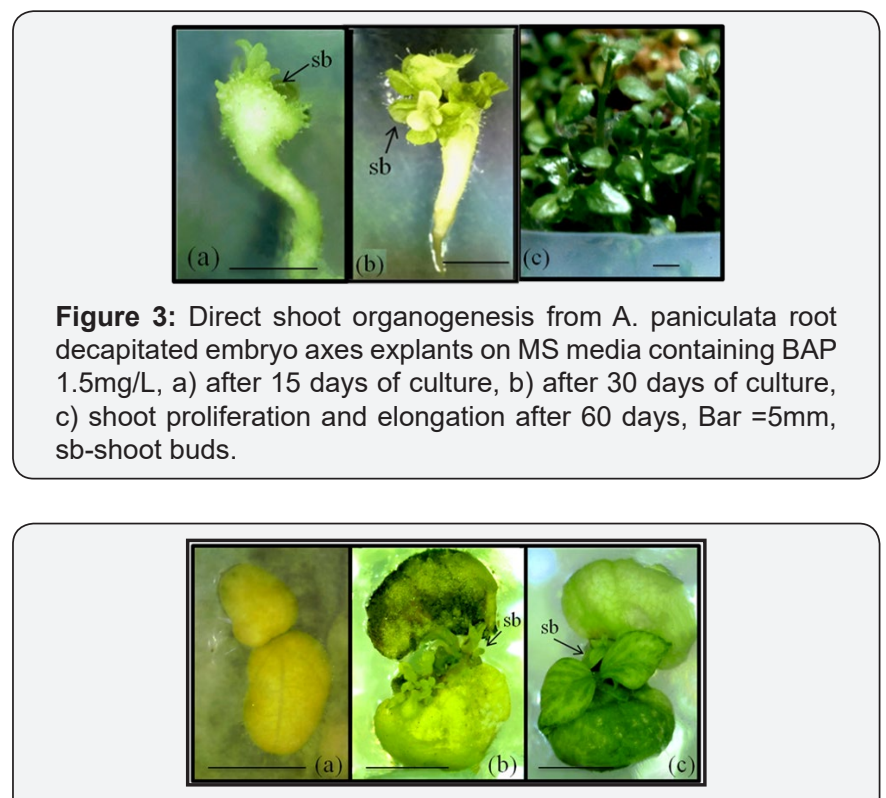

Figure 4: Direct shoot regeneration of $A$. paniculata cotyledon explants in different stages on MS media containing BAP $1.5 \mathrm{mg} / \mathrm{L}, \mathrm{a})$ cotyledon after 5 days of inoculation, b) after 15 days of culture, c) after 30 days of culture. sb-shoot buds, Bar=5mm.

Shoot regeneration and number of shoots depended on the type of cytokinin and its concentrations used. Among the different PGRs tested direct regeneration of shoot buds were maximum from embryonic axis segments cultured on Murashige and Skoog (MS) medium supplemented with BAP $1.5 \mathrm{mg} / \mathrm{L}$ with $73.3 \%$ shooting and 12.33 shoots per explant while study in cotyledons showed best response in BAP $3.0 \mathrm{mg} / \mathrm{L}$ with $52.2 \%$ shooting and 9.33 shoots per explant. The initiation of direct organogenesis was noticed by 15 days, with protuberances appearance at the cut edge of the explants which develop into shoot lets around 15 days. Shoot initials arose from the bulging in the apical region of the embryonal axes within 15 days of dark incubation (Figure 3) while shoots were formed directly from cut ends of the cotyledon (Figure 4) indicating the formation of shoot buds from pre-existing meristematic regions. The explants and their shoots became green under the influence of light and a few of these shoots were elongated and others stunted. The addition of auxins to BAP resulted in decreased or complete inhibition of shooting (Table 2 \& 3). IBA when added to BAP resulted in reduction of shooting response and number of shoots formed in both explants but the shoots formed faster, complete and longer than compared to BAP alone. While addition of NAA induced callus and completely inhibited the organogenesis process. The shoot cluster were cut into small clusters of 3-5 shoots per bunch and subcultured in BAP $1.5 \mathrm{mg} / \mathrm{L}$, significantly increased the rate of shoot multiplication by the end of the subculture resulting in 30-40 shoots/explant.

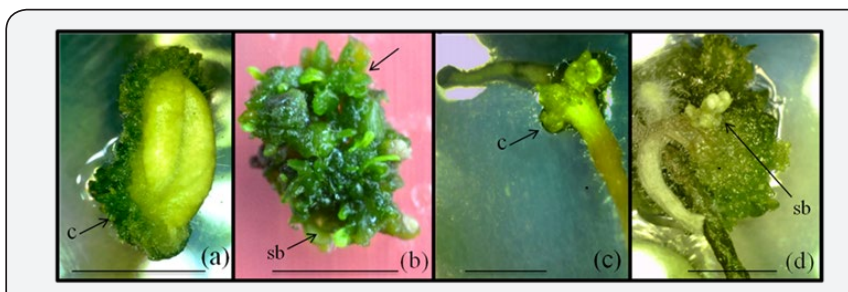

Figure 5: Indirect shoot organogenesis from A. paniculata embryonic explants on MS media containing TDZ $1.0 \mathrm{mg} / \mathrm{L}$, a) cotyledon explants after 15 days, b) cotyledon explants after 30 days, c) root decapitated embryonic axes explants after 15 days, d) root decapitated embryonic axes explants after 30 days. Bar $=1 \mathrm{~mm}, \mathrm{c}$-callus, sb-shoot buds

While indirect adventitious shoot organogenesis was observed in the case of TDZ treatments with maximum shoot regeneration of $26 \%$ from embryonic axis with 3.33 shoots and $76 \%$ from cotyledons with 6.0 shoots/explant at $1 \mathrm{mg} / \mathrm{L}$ of TDZ (Table 2, Table $3)$. On the media supplemented with different TDZ concentrations, both explants were initially developed in to full grown cotyledons and embryonic axes and later produced green friable calli. After three weeks shoot buds were differentiated on the surface of these calli in media containing TDZ $1.0 \mathrm{mg} / \mathrm{L}$ only (Figure 5). TDZ in the medium had induced higher frequency of organogenesis; however, the frequency of shoot formation was not as high as that of BAP. Therefore, these results suggest the use of BAP for efficient shoot multiplication from the cotyledonary and embryonic explants for $A$. paniculata conservation.

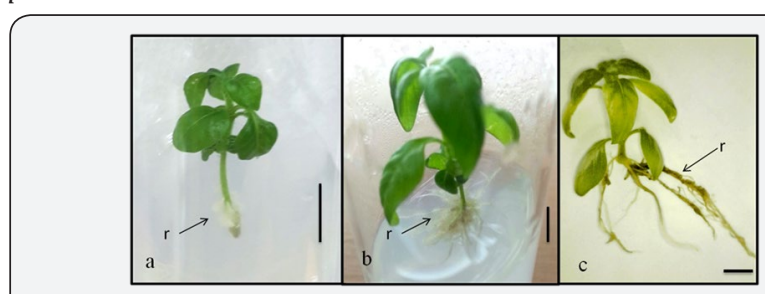

Figure 6: Rooting from shoots cultured on IBA, Bar $=1 \mathrm{~cm}$.

a)shoot with roots induced after 7 days of culture, b) shoot with roots after 15 days of culture, c) shoot with roots after 15 days of culture.

These microshoots when cultured in media supplemented with BAP $0.5 \mathrm{mg} / \mathrm{l}$, NAA $0.05 \mathrm{mg} / \mathrm{l}$ and GA3 $0.5 \mathrm{mg} / \mathrm{l}$ elongated into $2-3 \mathrm{~cm}$ long plantlets in 30-40 days. Elongated microshoots were efficiently 
rooted in half MS media containing IBA $0.5 \mathrm{mg} / \mathrm{L}$ (Figure 6) with $81 \%$ rooting percentage and the rooted plants were acclimatized successfully in green house with $82.5 \%$ survival.

\section{Discussion}

The type of explant is an important factor for morphogenesis in tissue culture. In the study for explants with multiple shooting capability, out of the 5 explants tested only cotyledons and embryonic axes with decapitated root end was able to produce shoots while embryos, embryo axes and decapitated embryo axes with both shoot and root tip didn't produce any result. Embryos and embryonic axes developed into plantlets where as decapitated embryo axes with both shoot and root tip. Embryonic axes generally have apical and auxiliary meristems at the junction of the cotyledon that are competent for regeneration [20]. In many previous studies using different embryonic explants, embryonic axis with decapitated root tip proved to be efficient in induction of organogenesis compared to non decapitated embryonic axes explants and shoot end decapitated embryonic axes explants [21]. This may be due to the decapitation of embryo axis which restricts is general path of developing into plantlet and results in accumulation of PGRs and multiple shoot induction from the meristematic ends of the embryo axes. The removing of root tip presumably prevents radicle growth which also might stimulate multiple shoot production [22]. Explant with shoot meristem was superior to explants without shoot meristem because meristem cells have the high capacity for producing callus and regenerating shoot [14]. While cotyledons have meristematic tissue at the junction of embryonic axis and cotyledon which is developed into shoots indicating an existence of a polar phenomenon effecting morphogenesis [23].

After 4 days of incubation in dark, bulging of the proximal end of the cotyledon and decapitated embryonal axis were observed. Shoot initials arose from the bulging in the cotyledons and from the apical region of the embryonal axes within 15 days of dark incubation. This observation indicates the necessity of exposure of the explants to dark period for the initial induction of shoot formation as was earlier reported for Zizyphus jujube [24] and Ricinus communis [19]. The chief characteristic of tissues grown in dark is preservation of light-sensitive endogenous or exogenous plant growth regulators [25].

Kulkarni et al. [26] stated that the threshold concentrations of growth regulators required for organogenic induction and optimal response differed for different explant types. Multiple shoots were successfully induced from decapitated embryonic axes using TDZ, BAP, Kinetin and Zeatin [16] and cotyledons using, BAP, 2iP, Kinetin and TDZ [27]. In the present study BAP and BAP with IBA and TDZ were effective in inducing shoots in both explants used compared to other hormones used. Among the cytokinins, the effectiveness of BAP was best, the frequency of organogenesis was higher than $50 \%$ in both explants and TDZ was better with shooting percentage of $76 \%$ for cotyledons and $26 \%$ for embryonic axis. However, the effectiveness of $2 \mathrm{iP}$ was quite week, their induction frequency was less than $20 \%$ and kinetin with no organogenesis. Similar results were observed in cassava with BAP and TDZ performing better than Kinetin and 2, iP [28]. While the number of shoots per explants in BAP is more compared to TDZ, 2 iP and KIN, similar kind of results were found in clonal propagation of Clitoria ternatea using decapitated embryonic axes explants the number of shoots/explant is significantly higher on BAP containing media than KIN and TDZ [17].

BAP induced adventitious shoot regeneration was previously reported from embryonic explants in crops such as Vigna unguiculata L. [29], Cajanus cajan [30] and Ochradenus arabicus [31] and also effective than KIN in nodal regeneration form Andrographis paniculata [32]. The superiority of BAP predicted might be due to its easy permeability and increased affinity for active cell uptake [33,34]. BAP when added alone in the medium was the most effective plant growth regulator indicating the cytokinin specificity of decapitated embryonic axes of C. ternatea for multiple shoot regeneration [17]. BAP at $1.5 \mathrm{mg} / \mathrm{L}$ was sufficient to induce maximum shooting in case of embryonic axis compared to $3 \mathrm{mg} / \mathrm{L}$ in cotyledons. High concentrations of BAP induced direct shoot regeneration from the cotyledonary surface [35] whereas low concentrations favoured development of shoots from preexisting meristem in embryonic axes [36]. This may be due to apical meristematic cells in the cotyledonary node which are sites for hormone synthesis and exhibit different needs of plant growth regulators for regeneration in comparison to other tissues [37]. In embryonic axes the increase of BAP more than $1.5 \mathrm{mg} / \mathrm{L}$ led to decreased shooting response and shoot number similar to results observed in lentil [38]. BAP $1-2 \mathrm{mg} / \mathrm{L}$ produced best response in embryo explants and decapitated embryo explants in previous studies.

Though it is well known that the concentration of auxin to cytokinin has a relative effect in the shoot organogenesis [39] in the present study the presence of auxin in the regeneration media decreased the efficiency of shoot induction by BAP which was observed when used alone. The above results were similar to a study in pigeon pea where $2.5 \mathrm{mg} / \mathrm{L}$ BAP induced higher regeneration of shoot buds but addition of NAA and IBA reduced the regeneration capacity of shoots [40]. In the present study though the shooting response was low in media with BAP and IBA compared to media devoid of IBA but the shoots formed early and they were complete and elongated compared to those formed in BAP. In studies on fenugreek $[41,42]$ reported the positive effects of IBA in the culture media on the shoot length. The addition of IBA to the medium containing BAP was effective in maintaining healthy shoot growth [43].

TDZ was earlier reported in many reports to enhance multiple shoot formation $[44,45]$. In the present study TDZ induced green nodular callus which in turn produced shoots which is similar in another study in Ricinus communis where green callus formed from cotyledonary nodes followed by shoot formation [19]. There have been several reports of significant TDZ effects on callus formation and shoot organogenesis in other species [24]. The 
formation of callus in TDZ treatments could be due to its auxin-like and cytokinin-like activity and can be substituted for auxins or the combination of auxins and cytokinins in shoot induction studies [46]. Though TDZ induced 76\% shoot regeneration in cotyledon explants the no of shoots developed is relatively less compared to BAP 3.0mg/L. According to Thiem [47] callus growth on explants usually interferes with the propagation process which may have affected the no of shoots in the present study. TDZ has been found to be most effective for multiple shoot induction from embryonic axis and cotyledons when used at a concentration of $1 \mathrm{mg} / \mathrm{L}$ similar to studies in Cicer arietinum and Pongamia pinnata [48].

When comparing the effect of cotyledon and decapitated embryonic axes explants on percentage of response and number of multiple shoots, the response of embryonic axes was better than cotyledon. Regeneration frequency is generally influenced by the type of explant and embryonic axes reacted better than the cotyledons [49] and whole embryonated cotyledon, sectional embryonated cotyledon, whole de-embryonated cotyledon, sectional de-embryonated cotyledon [50]. This is because of presence of apical and auxiliary meristematic tissue in the embryo axes that are primary sites of shoot regeneration compared to cotyledon which has a lesser amount meristematic tissue that is acquired from the embryonic axes during separation from embryonic axes.

For establishing an efficient micropropagation protocol, successful rooting of microshoots is a prerequisite to facilitate their establishment in soil. Throughout root induction studies, half strength MS basal medium was used due to the fact that low salt concentrations promote rooting [51]. The rooting media also needed to be void of cytokinin as cytokinin delays root establishment [52]. Concentration and type of auxin in the medium was found to be the critical factor in producing healthy roots. IBA has been widely used as a root inducing hormone in difficult-to-root plants both under in vitro and in vivo conditions [53-55] and IBA $0.5 \mathrm{mg} / \mathrm{L}$ is proved to be effective in previous studies in A. panicualta [56-59].

\section{References}

1. Calixto JB (2005) Twenty-five years of research on medicinal plants in Latin America. A personal view. J Ethnopharmacol 100(1-2): 131-134.

2. Chun YW (1993) Clonal propagation in non-aspen poplar hybrids In: Ahuja MR (Ed.), Micropropagation of woody plants. Kulwer Academic Publishers, Dordrecht, Netherlands, pp. 209-222.

3. Leva AR, Petruccelli R, Rinaldi LMR (2012) Somaclonal variation in tissue culture: A case study with olive. Recent Advances in Plant in vitro Culture, pp. 10-17.

4. Skirvin RM, McPheeters KD, Norten M (1994) Source and frequency of somaclonal variation. Hort Science 29(11): 1232-1237.

5. Ebrahimie E, Habashi AA, Mohammadie-Dehcheshmeh M, Ghannadha MR, Ghareyazie B, et al. (2006) Direct shoot regeneration from mature embryo as a rapid and genotype-independent pathway in tissue culture of heterogeneous diverse sets of cumin (Cuminum cyminum L.) genotypes. In Vitro Cell Dev Biol Plant 42(5): 455-460.

6. Tang W, Guo ZC (2001) In vitro propagation of loblolly pine via direct somatic organogenesis from mature cotyledons and hypocotyls. Plant Growth Regul 33(1): 25- 31.
7. Thamlikitkul V, Dechatiwongse T, Theerapong S, Chantrakul C, Boonroj P, et al. (1991) Efficacy of Andrographis paniculata, Nees for pharyngotonsillitis in adults. Journal of Medical Association of Thailand 74(10): 437-442.

8. Lim JCW, Chan TK, Ng DSW, Sagineedu SR, Stanslas J (2012) Andrographolide and its analogues: versatile bioactive molecules for combating inflammation and cancer. Clin Exp Pharmacol Physiol 39(3): 300-310.

9. Martin KP (2004) Plant regeneration protocol of medicinally important Andrographis paniculata (Burm. f.) Wallich ex Nees via somatic embryogenesis. In Vitro Cell Dev Biol Plant 40(2): 204-209.

10. Jiang Q, Zhang Y, Zhong C, Zeng B, Bogusz D, et al. (2012) Establishment of an in vitro plant regeneration protocol for Casuarina cunninghamiana Miq. via indirect organogenesis. New Forests 43(2): 143-154.

11. Chaturvedi R, Razdan MK, Bhojwani SS (2004) In vitro morphogenesis in zygotic embryo cultures of neem (Azadirachta indica A. Juss.). Plant Cell Reports 22(11): 801-809.

12. Nayak P, Behera PR, Thirunavoukkarasu M, Chand PK (2010) High frequency plant regeneration through adventitious multiple shoot organogenesis in epicotyl explants of Indian gooseberry (Emblica officinalis Gaertn). Scientia Horticulturae 123: 473-478.

13. Sailaja M, Tarakeswari M, Sujatha M (2008) Stable genetic transformation of castor (Ricinus communis L.) via particle gunmediated gene transfer using embryo axes from mature seeds. Plant Cell Rep 27(9): 1509-1519.

14. Khalafalla MM, Daffalla HM, Abdellatef E, Agabna E, El-Shemy HA (2011) Establishment of an in vitro micropropagation protocol for Boscia Senegalensis (Pers.) Lam. Ex Poir. J Zhejiang Univ Sci B 12(4): 303-312.

15. Prasad M, Guru TN, Prasad VKV, Sudhakar P (2011) In vitro proliferation of shoot regeneration from embryo of Cajanus cajan L (var.LGG-29). Journal of Developmental Biology and Tissue Engineering 3(5): 62-65.

16. Singh R, Srivatsava K, Jaiswal HK, Amla DV, Singh BD (2002) High frequency multiple shoot regeneration from decapitated embryo axes of chickpea and establishment of plantlets in the open environment. Biologia Plantarum 45(4): 503-508.

17. Singh J, Tiwari KN (2012) In vitro plant regeneration from decapitated embryonic axes of Clitoria ternatea L.-An important medicinal plant. Industrial Crops and Products 35: 224- 229.

18. Liu EE, Leung DWM, Xia QH, Zheng JR, Peng XX, et al. (2013) Efficient plant regeneration in vitro from cotyledon explants of chieh-qua (Benincasa hispida Cogn. var. chieh-qua). Science Asia 39: 134-138.

19. Ahn YJ, Chen GQ (2008) In vitro regeneration of castor (Ricinus communis L.) using cotyledon explants. Hort Science 43(1): 215-219.

20. Surekha Ch, Arundhati A, Rao GS (2007) Differential response of Cajanus cajan varieties to transformation with different strains of agrobacterium. Journal of Biological Sciences 7(1): 176-181.

21. Kadri A, Chalak L, El Bitar A, Nicolas N, Mroué S, et al. (2014) In vitro Plant Regeneration System for Two Middle East Cultivars of Chickpea (Cicer arietinum L.). Advance Crop Science and Technology 2: 125.

22. Polisetty R, Paul V, Deveshwar JJ, Khetarpal S, Suresh K, et al. (1997) Multiple shoot induction by benzyladenine and complete plant regeneration from seed explants of chickpea (Cicer arietinum L.). Plant Cell Rep 16(8): 565-571.

23. Sancak C, Mirici S, Özcan S (2000) High frequency shoot regeneration from immature embryo explants of Hungarian vetch. Plant Cell, Tissue and Organ Culture 61(3): 231-235.

24.Guo B, Abbasi BH, Zeb A, Xu LL, Wei YH (2011) Thidiazuron: A multi-dimensional plant growth regulator. African Journal of Biotechnology10(45): 8984-9000. 
25. Hutchinson MJ, Sanaratna T, Sahi SV, Saxena PK (2000) Light mediates endogenous plant growth substances in thidiazuron-induced somatic embryogenesis in geranium hypocotyl cultures. Journal of Plant Biochemistry and Biotechnology 9(1): 1-6.

26. Kulkarni AA, Thengane SR, Krishnamurthy KV (2000) Direct shoot regeneration from node, internode, hypocotyle and embryo explant of Withania somnifera. Plant Cell Tiss Org Cult 62(3): 203-209.

27. Tavallaie FZ, Ghareyazie B, Bagheri A, Sharma KK (2011) Lentil regeneration from cotyledon explant bearing a small part of the embryo axis. Plant Tissue Cult Biotech 21(2): 169-180.

28. Guohua M (1998) Effects of cytokinins and auxins on cassava shoot organogenesis and somatic embryogenesis from somatic embryo explants. Plant Cell Tiss Org Cult 54(1): 1-7.

29. Aasim M, Day S, Rezaei F, Hajyzadeh M (2013) Multiple shoot regeneration of plumular apices of chickpea. Turkish Journal of Agriculture and Forestry 37: 33-39.

30. Prasad M, Guru TN, Prasad VKV, Sudhakar P (2011) In vitro proliferation of shoot regeneration from embryo of Cajanus cajan L (var.LGG-29). Journal of Developmental Biology and Tissue Engineering 3(5): 62-65.

31. Nadeem M, Al-Qurainy F, Khan S, Tarroum M, Ashraf M (2012) Direct shoot multiplication in Ochradenus arabicus, an endemic medicinal plant of Saudi Arabia. Pakistan Journal of Botany 44(1): 345-347.

32. Purkayastha J, Sugla T, Paul A, Solleti S, Sahoo L (2008) Rapid in vitro multiplication and plant regeneration from nodal explants of Andrographis paniculata: a valuable medicinal plant. In Vitro Cell Dev Biol Plant 44(5): 442-447.

33. Cin VD, Boschetti A, Dorigoni A, Ramina A (2007) Benzylaminopurine application on two different apple cultivars (Malus domestica) displays new and unexpected fruitlet abscission features. Ann Bot 99(6): 11951202.

34. Pandey V, Agrawal V (2009) Efficient micropropagation protocol of Spilanthes acmella L. possessing strong antimalarial activity. In Vitro Cell Dev Biol Plant 45: 491-499.

35. Mehta U, Ram HYM (1980) Regeneration of plantlets from the cotyledons of Cajanus cajan L. Indian Journal of Experimental Biology 18: 800-802.

36. Prakash NS, Pental D, Bhalla- Sarin N (1994) Regeneration of pigeon pea (Cajanus cajan) from cotyledonary node via multiple shoot formation. Plant Cell Rep 13(11): 623-627.

37. Shimizu-Sato S, Tanaka M, Mori H (2009) Auxin-cytokinin interactions in the control of shoot branching. Plant Mol Biol 69(4): 429-435.

38. Rubluo A, Kartha KK, Mroginski LA, Dyck J (1984) Plant regeneration from pea leaflets cultured in vitro and genetic stability of regenerants. Journal of Plant Physiology 117(2): 119-130.

39. Devendra BN, Swarnalatha P, Srinivas N (2011) An efficient Multiple shoots induction from zygotic embryos and rhizomes of Zingiber roseum Rosc, an endangered medicinal plant. Annals of Biological Research 2(5): 329-337.

40. Krishna G, Reddy PS, Rambabu P, Sohrab SS, Rana D, et al. (2011) In vitro regeneration through organogenesis and somatic embryogenesis in pigeon pea (Cajanus cajan (L.) Millsp.) cv. JKR105. Physiol Mol Biol Plants 17(4): 375-385.

41. Aasim M, Khalid MK, Sebahattin O (2010) Efficient In vitro propagation from preconditioned embryonic axes of Turkish cowpea (Vigna unguiculata L.) cultivar Akkiz. Arch Biol SciBelgrade 62(4): 1047-1052.

42. Aasim M, Khawar KM, Sancak C, Özcan S (2009) In vitro shoot regeneration of Fenugreek (Trigonella foenumgraceum L.). Am-Eu J Sustain Agric 3: 135-138.

43. Wu JH, Miller SA, Hall HK, Mooney PA (2009) Factors affecting the efficiency of micropropagation from lateral buds and shoot tips of Rubus. Plant Cell Tiss Org Cult 99(1): 17-25.

44. Bhatnagar-Mathur P, Vadez V, Devi MJ, Lavanya M, Vani G, et al. (2009) Genetic engineering of chickpea (Cicer arietinum L.) with the P5CSF129A gene for osmoregulation with implications on drought tolerance. Molecular Breeding 23(4): 591-606

45. Patil G, Patel R, Jaat R, Pattanayak A, Jain P, et al. (2009) Glutamine improves shoot morphogenesis in chickpea (Cicer arietinum L.). Acta Physiologia Plantarum 5: 1077-1084.

46. Singh ND, Sahoo L, Sarin NB, Jaiwal PK (2003) The effect of TDZ on organogenesis and somatic embryogenesis in pigeon pea (Cajanus cajan L. Mill.). Plant Sci 164: 341-347.

47. Thiem B (2003) In vitro propagation of isoflavone-producing Pueraria lobata (Willd.) Ohwi Plant Science 165(5): 1123-1128.

48. Belide S, Sajjalaguddam RR, Paladugu A (2010) Cytokinin preconditioning enhances multiple shoot regeneration in Pongamia pinnata (L.) Pierre - a potential, non-edible tree seed oil source for biodiesel. Electronic Journal of Biotechnology 13(6): 1-9.

49. Keulemans J, de Witte K (1994) Plant regeneration from cotyledons and embryonic axes in apple: Sites of reaction and effect of pre-culture in the light. Euphytica 77(1): 135-139.

50. Palanivel S, Jayabalan N (2002) Direct Multiple Shoot Induction from Different Mature Seed Explants of Groundnut (Arachis hypogaea L.) Philippine Journal of Science 131(2): 127-131.

51. Nemeth G (1986) Induction of rooting. In: Bajaj YPS (Ed.), Biotechnology in agriculture and forestry 1, Tree 1. Springer, Berlin, Germany, pp. 4986.

52. Laplaze L, Benkova E, Casimiro I, Maes L, Vanneste S, et al. (2007) Cytokinins act directly on lateral root founder cells to inhibit root initiation. Plant Cell 19(12): 3889-3900.

53. Nagori R, Purohit SD (2004) In vitro plantlet regeneration in Annona squamosa through direct shoot bud differentiation on hypocotyl segments. Sci Hort 99(1): 89-98.

54. Nayak P, Behera PR, Thirunavoukkarasu M (2007) High frequency plantlet regeneration from cotyledonary node cultures of Aegle marmelos (L.). Corr In Vitro Cell Dev Biol Plant 43(3): 231-236.

55. Bansi TS, Rout GR (2013) Plant regeneration protocol of Andrographis paniculata (Burm. f.)-an important medicinal plant. African Journal of Biotechnology 12(39): 5738-5742.

56. Kataky A, Handique PJ (2010) Micropropagation and screening of antioxidant potential of Andrographis paniculata (Burm. f) Nees. Journal of Hill Agriculture 1(1): 15-20.

57. Gu XF, Zhang JR (2005) An efficient adventitious shoot regeneration system for Zhanhua winter jujube (Zizyphus jujuba Mill.) using leaf explants. Plant Cell Rep 23(12): 775-779.

58. Ignacimuthu S, Franklin G (1999) Regeneration of plantlets from cotyledon and embryonal axis explants of Vigna mungo L. Hepper. Plant Cell Tiss Org Cult 55(1): 75-78.

59. Werner T, Nehnevajova E, Köllmer I, Novák O, Strnad M, et al. (2010) Root-specific reduction of cytokinin causes enhanced root growth, drought tolerance, and leaf mineral enrichment in Arabidopsis and Tobacco. The Plant Cell 22(12): 3905-3920. 


\section{Your next submission with Juniper Publishers will reach you the below assets}

- Quality Editorial service

- Swift Peer Review

- Reprints availability

- E-prints Service

- Manuscript Podcast for convenient understanding

- Global attainment for your research

- Manuscript accessibility in different formats

( Pdf, E-pub, Full Text, Audio)

- Unceasing customer service

Track the below URL for one-step submission https://juniperpublishers.com/online-submission.php 